\title{
Analysis of Functional Foods and Active Ingredients used in Sports
}

\author{
Judit Molnár ${ }^{1}$ and Mahendra Pal ${ }^{2 *}$ \\ ${ }^{1}$ Dietitian, MSc in Food Safety and Quality Engineering; Ph.D. in Food Sciences -Palánkutca, Mosonmagyaróvár, Hungary. \\ ${ }^{2}$ Narayan Consultancy on Veterinary Public Health and Microbiology- Anand, Gujarat, India.
}

*Corresponding author: Mahendra Pal, Founder Director of Narayan Consultancy on Veterinary Public Health and Microbiology- Anand, Gujarat, India.

Received date: July 12, 2021; Accepted date: July 30, 2021; Published date: August 11, 2021

Citation: Molnár J. and Mahendra Pal. (2021). Analysis of Functional Foods and Active Ingredients used in Sports. J. Nutrition and Food Processing, 4(5); DOI:10.31579/2637-8914/059

Copyright: (C) 2021, Mahendra Pal. This is an open access article distributed under the Creative Commons Attribution License, which permits unrestricted use, distribution, and reproduction in any medium, provided the original work is properly cited.

Abstract
There are more and more group sports events and individual sporting opportunities in the world. In this case, a number of
factors need coordinated organ function. This requires an increased attention to the protection of the athlete's health. The
regular consumption of functional foods with physiologically active substances found in them can stimulate organ
function. Physiologically active ingredients in these functional foods include minerals, macronutrients, conjugated linoleic
acid, coenzyme Q10, probiotics, prebiotics, omega-3 fatty acids, choline, and vitamins. Their effect is also beneficial in
the functioning of the movement system, circulatory system, visceral organs, regulatory system and sensory system. Our
publication is aimed to analyze the organ systems used in the physical activity, the functional foods that affect them, and
the active ingredients in them. It is imperative to use nutritionally rich foods for keeping good health.
Keywords: functional foods; organ systems; physical activity; physiologically active components; sports

\section{Introduction}

Worldwide, more and more initiatives are being launched to promote the healthy eating and sports, which can contribute to protecting our health. With the emphasis on prevention, the nutritional needs of those who exercise physical activity must be met in a special way. This prevents the body from being overloaded. In the case of sports, the use of the body is more important than the average work. It is also necessary to consume 3000-6000 Kcal of energy and also change the ratio of macronutrients to normal consumption [1]. Extreme temperatures and temperature changes also play an important role in the workload of the body during hard physical work and sports [2]. These factors contribute to the loss of energy and thus increase the chance of weakening the body and the risk of exhaustion. The effect of heavy physical work on organ systems has also been investigated as the coordinated functioning of the systems of motion, circulatory organs, visceral, regulatory organs and sensory organs plays a significantrole [3]. In the case of this strain, a coordinated functioning of the skeletal and musculoskeletal system is required within the movement system and the system of the circulatory organs is also loaded, primarily focusing on the functioning of the heart. The respiratory system plays a prominent role in visceral systems, while the digestive system is at rest. The nervous system plays a role in the management of the previously discovered processes. Maintaining the functioning of our senses and protecting their health also contribute to the professional work [4].
Therefore, maintaining the health, maintaining the body and organ systems plays a prominent role in the provision of food for active athletes. In order to put this into practice, the functional foods are placed in the center of nutritional recommendations in the right form, even with alternative solutions, because of the active ingredients they contain. In order to protect the health and prevent disease, one of the most important tasks of food manufacturing professionals has been the production of products with these functional properties. We consider it important to use them in our publications with the help of our presentations, and to ensure well-being for those who want to do sports. In order to find this, we have already addressed in our previous paper how to meet the nutritional needs of human resources and its alternatives [5]. However, the relationships between the organ systems used during sporting activities, the functional foods that stimulate them and the physiologically active substances found in them have not yet been discovered. Therefore, we have set the goal of summarizing the organ systems to the functional foods that have beneficial effects on them and their active ingredients. The primary objective of this communication is to delineate the growing significance of functional foods and active ingredients for the sports.

\section{Presentation and importance of functional foods}

The concept of functional foods has already been formulated by a number of nations but a single law is still not born of these foods. Among the most 
prominent are the Japanese Ministry of Health and Welfare, the American Dietetic Association, the Health Canada, the International Food Information Council (IFIC) and the North American Institute of Life Sciences. However, there are factors that make functionality a reality. These benefits include physiological, health and nutritional benefits, wellknown applications, proof of research and development results, and foodform appearance. Accordingly, the product is not considered to be a medicinal product or a dietary supplement. The incorporation of these foods into a balanced diet is becoming increasingly significant. In a suitable form (even dried), they complement the food supply of persons who exercise physical activity and exercise extreme conditions.

The functional food can be grouped in several pictures. They can be distinguished by their origin, effect on health and how they are produced. Originally, the functional food of animal and plant origin can be distinguished by analyzing the active substances found in them, which are related to the effects on the organ system and the physiological functioning of the organism.

Based on their method of production, we can distinguish between whole foods, raw materials, added additives, enriched foods, increased content values- and real functional foods [6].
Physiologically active substances found in functional properties have been shown to have beneficial effects on the body, but they cannot be confused with the effects of the drugs or the content of the drug. Due to their positive physiological effect, the relationship between the individual organ systems and functional products, and the examination of their benefits, is a priority research area. These research findings have been formulated in numerous publications [7-9].

\section{The role of physiologically active substances in the workload of the body}

The functional foods with the active ingredients contained in them are able to positively regulate the physiological processes of the body and to improve the well-being. Many studies have shown that these drugs or their amounts can be increased in functional products during their development. These development options include enrichment, transformation and enhancement. In addition, the amount of these active ingredients can be increased by feeding, which is also a frequently used method today. Maintaining an equilibrium function of each organ system is important for heavy physical work and requires extreme attention under extreme working conditions. To this end, in our publication, as part of our work, we have summarized the organ systems, the most important active ingredients and the functional foods containing them ( Table 1).

\begin{tabular}{|c|c|c|c|}
\hline & Organ systems & Active substance content & Functional foods \\
\hline 1. & $\begin{array}{c}\text { Movement system: } \\
\text { skeleton- and muscle } \\
\text { system }\end{array}$ & $\begin{array}{c}\text { Magnesium; calcium; } \\
\text { protein }\end{array}$ & $\begin{array}{c}\text { Milk and milk products; } \\
\text { milk substitute fortified } \\
\text { vegetable drinks }\end{array}$ \\
\hline 2. & Circulatory system & Coenzyme Q10 & $\begin{array}{c}\text { Special beverages enriched } \\
\text { with Q10; beef }\end{array}$ \\
\hline 3. & $\begin{array}{c}\text { Visceral organs: Highlights } \\
\text { include digestive and } \\
\text { respiratory systems }\end{array}$ & $\begin{array}{c}\text { Conjugated linoleic acid; } \\
\text { probiotics; prebiotics }\end{array}$ & $\begin{array}{c}\text { Probiotic and prebiotic- } \\
\text { enriched milk and dairy } \\
\text { products }\end{array}$ \\
\hline 4. & $\begin{array}{c}\text { Systems of regulatory } \\
\text { bodies: including nervous } \\
\text { system }\end{array}$ & $\begin{array}{c}\text { Omega-3 fatty acid; } \\
\text { colin }\end{array}$ & $\begin{array}{c}\text { Sea fish enriched with } \\
\text { active ingredient }\end{array}$ \\
\hline 5. & System of sensory organs & $\begin{array}{c}\text { Vitamin A and E; minerals: } \\
\text { magnesium }\end{array}$ & $\begin{array}{c}\text { Vegetables and fruits; } \\
\text { vitamin-enriched functional } \\
\text { foods }\end{array}$ \\
\hline
\end{tabular}

Table 1. Organic systems- Active ingredients- Functional foods

In our publication, the presentation of functional foods, their practical application and development is important in order to provide products that can be integrated into the physical activity, in a form that ensures the nutrition of athletes with long-term shelf-life by preserving their nutritional values [10].

\section{Examination of consumption opportunities}

For the practical implementation of the dietary properties and functional foods, we have formulated recommendations for menu design. For functional foods included in the menu design, due regard to the conditions of use (athletes), particular consideration should be given to the shelf life and the way the food is packaged. To this end, predictive modeling is recommended in its experimental phases [11]. Focusing on the difficulty of working, the prescribed five-fold meal needs to be supplemented in many cases, which can be provided with multiple meals taking into account the appropriate protein, fat and carbohydrate ratios. Moreover, the ratio of proteins, complex carbohydrates and unsaturated fats should be changed to increase the energy content. In addition to traditional foods, which in many cases can be considered functional foods, the incorporation of enriched and enriched foods into the diet plays an important role. These enriched and enriched foods include supplements with vitamins, minerals, amino acids, and many more.
The use of alternative protein sources (single cell proteins) has been formulated in a number of technical literature, since a suitable amino acid set is provided to the body by proper exploration of the cell wall [12]. The intake of vitamins, minerals, and antioxidants required for human nutrition can be increased with the help of either the wood based connector or the beneficial agent applied to the ground. In addition, the quality of feed used in animal nutrition also determines the quality of meat subsequently consumed in order to increase the content of the active ingredient. Fibers of importance for human nutrition can be increased in food by proper selection of cereals, ensuring their functional functionality. Fluid consumption becomes an even more important factor in sports, as hydration of the body can prevent the occurrence of diseases and provide the surplus fluid required under extreme temperature conditions. Clean water is recommended for this purpose, but in many cases isotonic drinks (sports drinks) are produced for this purpose, which can replace the lost electrolyte from the body [13]. The detailed information on the role of liquid foods and beverages, particularly in elderly people is described by Molnár and Pal in 2020 [14].

Protecting our environment is of great importance today. The replacement of animal products with alternative solutions, clean water consumption, and the incorporation of vegetables and fruits into the diet have become 
part of environmental sustainability, both in the production and food processes.

\section{Conclusion}

During our research, we examined the functional foods acting on the organ systems used during sporting activities and the physiologically active substances found therein. We also provided menu design suggestions. During our evaluation of our results, we found a correlation between the consumption of high protein foods and the effectiveness of physical activity. However, it was found that the shelf life of mainly dairy products (fermented dairy products) may be difficult during sports, especially in extreme temperature conditions. That is why we recommend incorporating alternative cell sources into the diet. In addition, the use of drying technologies can increase the quality and safety of the food one wants to keep for a long time. We also considered it important to mention the protection of our environment, which also plays a major role in maintaining the human nutrition. It is hoped that this publication can contribute to the promotion of active sports for professionals in the field of food and sports sciences.

\section{Acknowledgement}

The authors are very thankful to Prof.Dr.R.K.Narayan for going through the manuscript.

\section{Contribution of authors}

All the authors contributed equally. They read the final version, and approved it for the publication.

\section{Conflict of interest}

The authors declare that they do not have any conflict of interest.

\section{Source of grant}

There was no financial support from any organization.

\section{References}

1. Rodler I (2005):Új Tápanyagtáblázat. (New NutrientTable) Budapest: Medicina Könyvkiadó Rt. /Book/35-37.
2. Kuti R (2011): Chemical relief Designed to Field Requirements, Process of Human Resources and Technical Conditions. Fire and Disaster Protection Civil Defense Review (ISSN 1218-2958) (Requirements For The Construction of a Chemical Disposal Site, Personal and Technical Conditions of the Procedure). Protection Disaster, Fire and Civil Protection Review.18:26-27.

3. Kardos L (2017): Anatómia-Élettan. (Anatomy-Physiology). Budapest: Müszaki Könyvkiadó /Book/:1-356.

4. Donáth T (2015): Anatómia-Élettan. (Anatomy-Physiology). Budapest: Medicina Könyvkiadó Zrt. /Book/:1-396.

5. Molnár J, Molnár R, Kóródi Gy (2016): Analysis of resupply of energy for workforce accomplishing long term damage cleanup duties. Academic and Applied Research in Military and Public Management Science. 15:223-229.

6. Nagy J, Schmidt J, Jávor A (2018): A jövő élelmiszerei és az egészség. (Food and health of the future). Debrecen: Center - Print Nyomda. /Book/:1-211.

7. Ashaolu T J (2020): Immune boosting functional foods and their mechanisms: A critical evaluation of probiotics and prebiotics. Biomedicine and Pharmacotherapy. 130:1-11.

8. Díaz L D, Fernández-Ruiz V, Cámara M (2020): An international regulatory review of food health related claims in functional food products labeling. Journal of Functional Foods. 68:1-14.

9. Tadesse S A, Emire S A (2020): Production and processing of antioxidant bioactivepeptids: A driving force for the functional food market.Heliyon. 6:1-11.

10. Csapó J, Albert Cs (2018):Funkcionális Élelmiszerek. (Functional Foods). Debreceni Egyetem. /Book/:1-282.

11. Szatmári J (2013): Models in Geoinformatics. (Models in Geoinformatics). University of Szeged, University of Debrecen, University of Pécs: /Book/1-189.

12. Molnár J and Pal M (2002):Applying single cell protein as functional foods. Journal of Microbiology, Immunology and Biotechnology. 7: 33-35.

13. Tihanyi A (2012): Performance Enhancer Sports Nutrition. (Performance Enhancing Sports Nutrition). Budapest: Krea-Fitt. /Book/: 1-311.

14. Molnar J and Pal M(2002):Role of liquid foods and beverages to prevent dehydration especially in eldely people. Journal of Nutrition and Food Processing. 3: 1-2.
This work is licensed under Creative Commons Attribution 4.0 License

To Submit Your Article Click Here: Submit Article
Ready to submit your research? Choose Auctores and benefit from:

* fast, convenient online submission

* rigorous peer review by experienced research in your field

* rapid publication on acceptance

* authors retain copyrights

* unique DOI for all articles

* immediate, unrestricted online access

At Auctores, research is always in progress.

Learn more www.auctoresonline.org/journals/nutrition-and-foodprocessing 